\title{
Proteomic analysis of human vitreous fluid by fluorescence- based difference gel electrophoresis (DIGE): a new strategy for identifying potential candidates in the pathogenesis of proliferative diabetic retinopathy
}

\author{
M. García-Ramírez • F. Canals • C. Hernández • N. Colomé • \\ C. Ferrer • E. Carrasco • J. García-Arumí • R. Simó
}

Received: 17 October 2006 / Accepted: 21 December 2006 / Published online: 23 March 2007

(C) Springer-Verlag 2007

\begin{abstract}
Aims/hypothesis The aim of this study was to compare the protein profile of vitreous fluid from diabetic patients with proliferative diabetic retinopathy (PDR) with that from nondiabetic patients with idiopathic macular holes $(\mathrm{MH})$. The mRNA of proteins differentially produced was also assessed in the retinas from diabetic and non-diabetic donors.

Materials and methods Vitreous humour from type 1 diabetic patients with PDR $(n=8)$ and from non-diabetic patients with $\mathrm{MH}(n=10)$ closely matched in terms of age were studied. The comparative proteomic analysis was performed using fluorescence-based difference gel electrophoresis (DIGE). Differentially produced proteins (abundance
\end{abstract}

Electronic supplementary material The online version of this article (doi:10.1007/s00125-007-0627-y) contains supplementary material, which is available to authorised users.

The first two authors contributed equally to this work.

M. García-Ramírez • C. Hernández $\cdot$ E. Carrasco $\cdot$ R. Simó $(\bowtie)$ Diabetes Research Unit, Endocrinology Division,

Vall d'Hebron University Hospital Research Institute,

Pg. Vall d'Hebron 119-129,

08035 Barcelona, Spain

e-mail: rsimo@ir.vhebron.net

F. Canals $\cdot$ N. Colomé $\cdot$ C. Ferrer

Proteomics Laboratory, Medical Oncology Research Programme,

Vall d'Hebron University Hospital Research Institute,

Barcelona, Spain

J. García-Arumí

Ophthalmology Department,

Vall d'Hebron University Hospital Research Institute,

Barcelona, Spain ratio $>1.4, p<0.05$ ) were identified by mass spectrometry. Expressions of mRNA were measured by real-time RT-PCR in retinas from ten human eyes obtained at post-mortem (five eyes from diabetic subjects and five eyes from non-diabetic subjects).

Results Eight proteins were highly produced in PDR patients in comparison with non-diabetic subjects: zinc$\alpha_{2}$-glycoprotein (ZAG), apolipoprotein (apo) A1, apoH, fibrinogen $\mathrm{A}$, and the complement factors $\mathrm{C} 3, \mathrm{C} 4 \mathrm{~b}, \mathrm{C} 9$ and factor $\mathrm{B})$. We found three proteins that were underproduced in PDR subjects: pigment epithelial derived factor (PEDF), interstitial retinol-binding protein (IRBP) and inter- $\alpha$ trypsin inhibitor heavy chain (ITIH2). There was no overlap in the vitreous levels of the above-mentioned proteins between PDR patients and non-diabetic control subjects. The differential production of $\mathrm{ZAG}, \mathrm{C} 3$, factor $\mathrm{B}$, PEDF and IRBP was further confirmed by western blot, and was in agreement with mRNA levels detected in the retina. Conclusions/interpretation Proteomic analysis by DIGE, which permits an accurate quantitative comparison, was useful in identifying new potential candidates involved in the pathogenesis of PDR.

Keywords Diabetic retinopathy DIGE - Proteomics . Retina $\cdot$ Type 1 diabetes $\cdot$ Vitreous fluid

Abbreviations
$\begin{array}{ll}\text { 2-DE } & \text { two-dimensional electrophoresis } \\ \text { apo } & \text { apolipoprotein } \\ \text { CHAPS } & \text { 3-[(3-cholamidopropyl }) \text { dimethylammonio]- } \\ & \text { 1-propanesulfonate }\end{array}$




$\begin{array}{ll}\text { DIGE } & \begin{array}{l}\text { fluorescence-based difference gel } \\ \text { electrophoresis }\end{array} \\ \text { IRBP } & \begin{array}{l}\text { interstitial retinol-binding protein } \\ \text { ITter- } \alpha \text {-trypsin inhibitor heavy chain }\end{array} \\ \text { MALDI- } & \begin{array}{l}\text { matrix-assisted laser desorption ionisation- } \\ \text { MS }\end{array} \\ \text { mass spectrometry } \\ \text { MH } & \text { macular holes } \\ \text { PEDF } & \text { pigment epithelial-derived factor } \\ \text { PDR } & \text { proliferative diabetic retinopathy } \\ \text { ZAG } & \text { zinc- } \alpha_{2} \text {-glycoprotein }\end{array}$

\section{Introduction}

Proliferative diabetic retinopathy (PDR) is a leading cause of blindness and visual impairment among adults aged $<40$ years in the developed world [1]. Investigations into the processes involved in PDR and the testing of new therapies are limited because of the unavailability of human retina samples and the lack of diabetic animal models that faithfully replicate the features of human PDR. In this regard, vitreous fluid obtained from diabetic patients undergoing vitreoretinal surgery is currently used as a surrogate for the retina in clinical research. However, there are two main confounding factors that could lead to misinterpretation of the results. First, vitreous haemorrhage, which often occurs in PDR, can produce a massive influx of serum proteins, thus precluding the usefulness of the vitreous fluid when studying the intraocular production of a particular protein. Second, the disruption of the bloodretina barrier that occurs in diabetic retinopathy produces an increase in proteins in the vitreous body of diabetic patients. Indeed, we have repeatedly detected three- to fourfold higher levels of intravitreal proteins in diabetic patients than in non-diabetic subjects [2-4]. Therefore, an elevated intravitreal level of a particular protein does not necessarily indicate an increase in intraocular production, and might simply reflect a non-specific increase in protein levels due to serum diffusion. In recent years, these problems have been solved by using a simple methodology that has enabled us to rationalise the use of vitreous fluid as a tool for assessing the intraocular production of various angiogenic and anti-angiogenic factors [5]. Nonetheless, the volume of vitreous fluid obtained after vitrectomy is approximately $1 \mathrm{ml}$ and, therefore, only a few peptides can be analysed simultaneously.

The recent development of proteome analysis has made it feasible to analyse protein profiles in various cells, tissues and body fluids with only a small sample [6]. However, few proteome analyses in human vitreous fluid have been performed in the setting of diabetic eye disease [7-11], and no previous quantitative proteomic comparison has been reported. The aim of the present study was to compare the protein profile of human vitreous fluid from diabetic patients with PDR with that of vitreous fluid obtained from nondiabetic patients with idiopathic macular holes $(\mathrm{MH})$, a condition in which, in contrast to PDR, the retina is not affected by neovascularisation. Apart from taking into account the main confounding factors, discussed above (vitreous haemorrhage and intravitreal protein concentration) subjects who had undergone laser photocoagulation in the preceding 6 months were excluded. This is because a significant alteration in the balance of intravitreal growth factors and transcriptional activity in the retina has been shown following this procedure [12]. To carry out this comparative proteomic analysis, we used fluorescence-based difference gel electrophoresis (DIGE) [13]. This technique provides an accurate quantitative comparison of the two groups of samples, allowing the identification of proteins whose levels differ significantly between the two conditions. We also measured the mRNA of proteins differentially produced in retinas from diabetic and non-diabetic donors.

\section{Subjects and methods}

Subjects and sample selection Eight vitreous humours from type 1 diabetic patients with active PDR and ten vitreous humours from non-diabetic patients with macular hole $(\mathrm{MH})$, closely matched in terms of age ( $48.7 \pm 11$ vs $48.3 \pm$ 10 years; $p=\mathrm{ns}$ ) were selected from our vitreous bank. The exclusion criteria were as follows: (1) previous vitreoretinal surgery; (2) photocoagulation in the preceding 6 months; (3) recent vitreous haemorrhage ( $<3$ months before vitrectomy) or intravitreous haemoglobin $>5 \mathrm{mg} / \mathrm{ml}$; (4) renal failure (creatinine $\geq 120 \mu \mathrm{mol} / \mathrm{l}$ ); and (5) other chronic diseases apart from diabetes. Details of vitrectomy and sample collection have been described previously elsewhere [3].

Five eyes were obtained at post-mortem from diabetic donors who were free from fundoscopic abnormalities in ophthalmological examinations performed during the preceding 2 years. Five eyecups obtained from non-diabetic donors matched in terms of age were used as the control group. The time elapsed from death to eye enucleation was less than $6 \mathrm{~h}$. After enucleation, eyes were snap-frozen in liquid nitrogen and stored at $-80^{\circ} \mathrm{C}$.

The protocol for sample collection was approved by the hospital ethics committee, and informed consent was obtained from the patients. The study was conducted in accordance with the principles of the Declaration of Helsinki.

Vitreous haemoglobin and total protein content Vitreous haemoglobin and intravitreal protein levels were measured by spectrophotometry and microturbidimetry, respectively. 
The detailed procedures are described in the Electronic supplementary material.

Sample preparation for two-dimensional gel electrophoresis proteomic analysis Samples for the proteomic analysis were prepared from four vitreous humours from PDR patients and from six vitreous humours from non-diabetic patients with MH. Samples were concentrated by ultrafiltration. Affinity chromatography was used to remove albumin and $\mathrm{IgG}$ from the samples, which were then further purified by acetone precipitation. The detailed procedures are described in the Electronic supplementary material.

$D I G E$ Protein concentration was adjusted to $2 \mathrm{mg} / \mathrm{ml}$ by the addition of a DIGE labelling buffer $(7 \mathrm{~mol} / 1 \mathrm{urea}, 2 \mathrm{~mol} / \mathrm{l}$ thiourea, 4\% w/v 3-[(3-cholamidopropyl) dimethylammonio]1-propanesulfonate [CHAPS], $30 \mathrm{mmol} / \mathrm{l}$ Tris, $\mathrm{pH}$ 8.0). A pool consisting of equal amounts of each of the samples analysed in the experiment was prepared as an internal standard for quantitative comparisons [14]. To avoid any possible bias introduced by labelling efficiency, half of the samples from each group were labelled with Cy3 dye and the other half with Cy5 dye. A third fluorescent dye, Cy2, was used to label the internal standard sample. Labelling was carried out by the addition of 400 pmol of the required $\mathrm{Cy}$ dye in $1 \mu \mathrm{l}$ of anhydrous $N, N$-dimethylformamide per $50 \mu \mathrm{g}$ of protein. After 30 min of incubation on ice in the dark, the reaction was quenched with $10 \mathrm{mmol} / \mathrm{l}$ lysine and the samples incubated for a further $10 \mathrm{~min}$. Samples were combined according to the experimental design, using $50 \mu \mathrm{g}$ of protein per $\mathrm{Cy}$ dye per gel, and diluted twofold with isoelectric focusing (IEF) sample buffer $(7 \mathrm{~mol} / \mathrm{l}$ urea, $2 \mathrm{~mol} / \mathrm{l}$ thiourea, $4 \% \mathrm{w} / \mathrm{v}$ CHAPS, $2 \%$ dithiothreitol [DTT], 2\% pharmalytes, $\mathrm{pH} 3-10$ ). One PDR and one $\mathrm{MH}$ sample, together with an aliquot of the internal standard pool, were then separated by two-dimensional electrophoresis (2-DE) in each of the gels (Fig. 1). This experimental design allows the accurate quantification and statistical assessment of the differences in protein abundances observed between the two sample groups [13].

2-DE was performed using reagents and equipment from GE Healthcare (Fairfield, CT, USA) (for details see the Electronic supplementary material).

Fluorescence images of the gels were obtained on a Typhoon 9400 scanner (GE Healthcare). Cy2, Сy3 and Cy5 images were scanned at excitation/emission wavelengths of $488 / 520 \mathrm{~nm}, 532 / 580 \mathrm{~nm}$ and $633 / 670 \mathrm{~nm}$, respectively, at a resolution of $100 \mu \mathrm{m}$. Both image analysis and statistical quantification of relative protein levels were performed using DeCyder v. 5.0 software (GE Healthcare).

Protein identification by mass spectrometry Protein spots of interest were excised from the gel using an automated spot picker (GE Healthcare). In-gel trypsin digestion was performed as described previously [14], using autolysis-stabilised trypsin (Promega, Madison, WI, USA). Tryptic digests were purified using ZipTip microtitre plates (Millipore, Billerica, MA, USA).

Peptide mass fingerprint by matrix-assisted laser desorption ionisation-mass spectrometry (MALDI-MS) was used for protein identification. The detailed procedures are described in the Electronic supplementary material.

Western blot analysis Aliquots of samples used in the DIGE experiments were analysed by western blotting to investigate five of the proteins shown by DIGE to be differentially produced in vitreous fluid from PDR patients as compared with vitreous fluid from non-diabetic patients with $\mathrm{MH}$ (zinc- $\alpha_{2}$-glycoprotein $[\mathrm{ZAG}], \mathrm{C} 3$, factor $\mathrm{B}$, pigment epithelial-derived factor [PEDF] and interstitial retinol-l-binding protein [IRBP]). To further evaluate the reproducibility of DIGE, eight additional vitreous samples (four PDR and four MH) were analysed by western blot analysis. For normalisation purposes, an equivalent amount $(5 \mu \mathrm{g})$ of soluble protein from vitreous fluid was loaded onto the gel. The detailed procedures are described in the Electronic supplementary material. Western blot analysis of ZAG, C3, factor B, PEDF and IRBP was also performed in serum obtained during vitrectomy according to this protocol.

Quantitative real-time RT-PCR Total RNA was extracted from isolated retinal tissues using the RNeasy Mini Kit with DNAse digestion (Qiagen Distributors, IZASA, Barcelona, Spain) according to the manufacturer's instructions. A $1 \mu \mathrm{g}$ sample of total RNA was used directly for reverse transcription, which was carried out using random hexanucleotide primers and TaqMan Reverse Transcription Reagents (Applied Biosystems, Madrid, Spain) in a $50 \mu \mathrm{l}$ reaction volume, according to the protocol provided by Applied Biosystems.

Quantitative real-time RT-PCR using specific primers (TaqMan pre-made gene expression assay Hs0017267; Applied Biosystems; Gene Bank RefSeq NM 000799.2) was performed, using $2 \mu \mathrm{l}$ of the reverse transcription reaction as a template in a PCR reaction set up with the TaqMan Universal Mastermix. After $10 \mathrm{~min}$ at $95^{\circ} \mathrm{C}$, the amplification reaction was carried out through 50 cycles $\left(95^{\circ} \mathrm{C}\right.$ for $15 \mathrm{~s}$ followed by $60^{\circ} \mathrm{C}$ for $\left.60 \mathrm{~s}\right)$ using Applied Biosystems 7000 equipment. Each sample was assayed in duplicate, and negative controls were included in each experiment. Automatic Relative Quantification data were obtained using ABI Prism 7000 Sequence Detection System software (Applied Biosystems), using the gene for $\beta$-actin as an endogenous gene expression control (Hs9999903_m1; Applied Biosystems). 
a
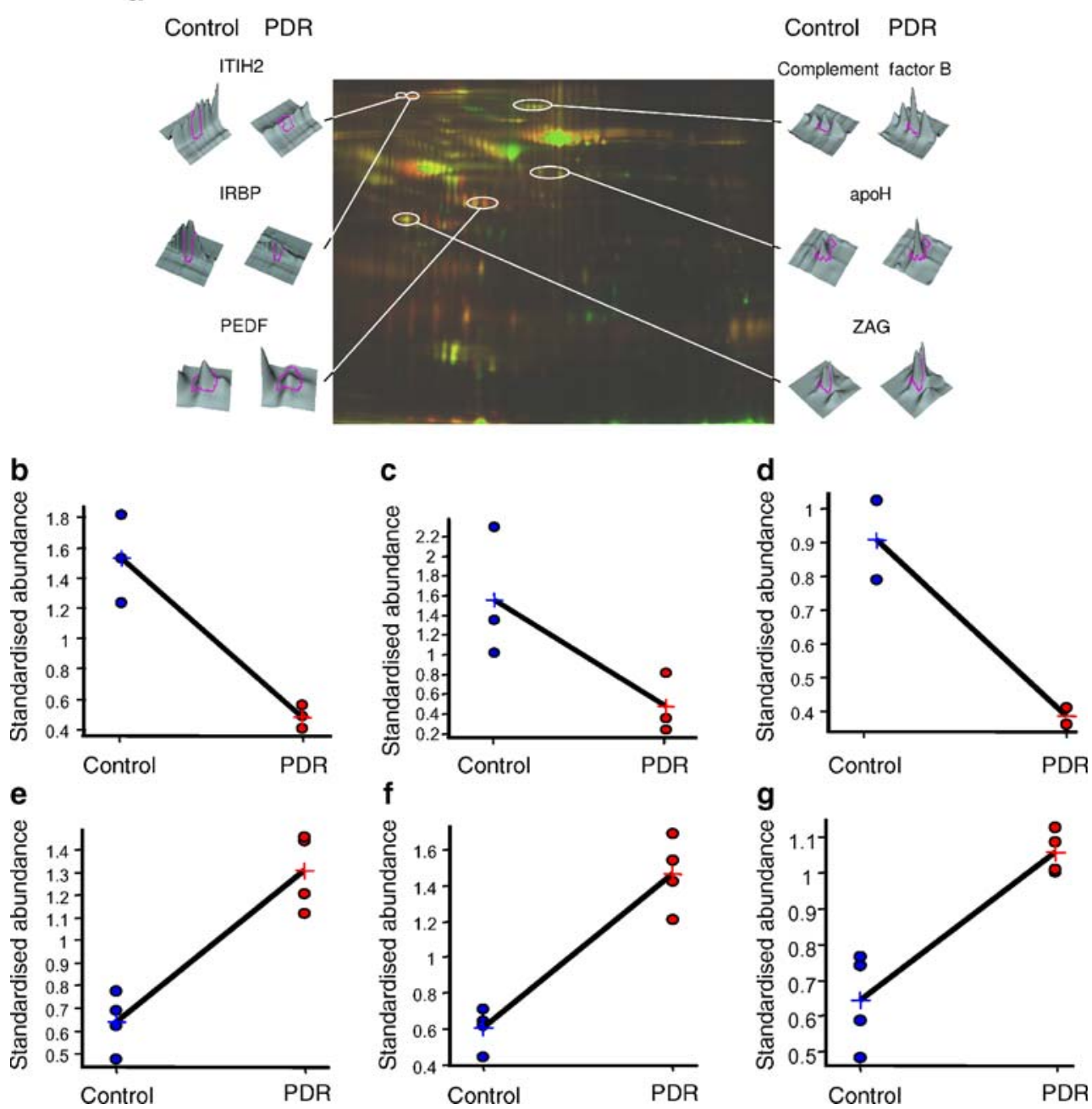

Fig. 1 a Superimposed images in pseudocolour from $\mathrm{Cy} 3$ (green, PDR vitreous proteins) and Cy5 (red, MH vitreous proteins) labelled samples run on a two-dimensional DIGE gel. The range of the horizontal dimension is isoelectric point $(\mathrm{pI})=3$ (left) to $\mathrm{pI}=10($ right $)$. The vertical dimension range from $\sim 15 \mathrm{kDa}$ (bottom) to $\sim 200 \mathrm{kDa}$ (top). The positions of the spots corresponding to the three proteins most increased and decreased in abundance are marked. Flanking the two-dimensional gel image are the three-dimensional images of these spots, corresponding to the $\mathrm{Cy} 5$ image (control $\mathrm{MH}$, left-hand panel for each protein), and the $\mathrm{Cy} 3$ image (PDR, right-hand panel for each

protein). b-g Standardised abundance plots for ITIH2 (b), IRBP (c), PEDF (d), factor B (e), apoH (f) and ZAG (g). Each graph displays the abundance observed for the spot in each of the four gel images corresponding to control MH samples (blue circles) and PDR samples (red circles), after standardising the values using the internal standard pool images (Cy2) of each of the four gels. The line links the average abundance values for each group of samples (crosses). Calculation of a Student's $t$ test for the difference in abundance between each two groups results in $p$ values of $<0.05$ in all cases shown

Statistical analysis All values are expressed as means \pm SD. Statistical significance between groups was analysed using the unpaired Student's $t$ test. A $p$ value of less than 0.05 was considered statistically significant.

\section{Results}

DIGE The mean protein contents were $4.45 \pm 1.4 \mathrm{mg} / \mathrm{ml}$ for PDR samples and $1.96 \pm 0.5 \mathrm{mg} / \mathrm{ml}$ for $\mathrm{MH}$ samples. Following depletion of the two most abundant protein types - serum albumin and $\mathrm{IgG}$ - by affinity chromatography, approximately $20 \%$ of the total protein was recovered, with little variation between the different samples. Identical amounts of the depleted protein mixture were analysed for each group. It can therefore be reasonably assumed that the depletion procedure does not significantly alter the abundance ratios between the two groups of samples.

Approximately 1,400 protein spots were detected. Selecting an abundance ratio of PDR:control of 1.4-fold as the threshold for study, 41 spots were differentially produced ( $p<0.05$, Student's $t$ test) in the vitreous samples from PDR patients (28 of them showing an increase and 13 a decrease) compared with those from the $\mathrm{MH}$ control group. The corresponding gel spots were excised and digested in-gel with trypsin. Following MALDI-MS time- 
of-flight/time-of-flight analysis we were able to identify 11 proteins, the levels of eight of which were increased and three were decreased in the vitreous fluid of PDR patients compared with the vitreous fluid of MH patients (Table 1). Most of these proteins were identified in several spots, consistent with the presence of different post-translational modification forms, probably resulting from different glycosylation. Figure 1 shows the positions of the spots corresponding to the proteins with the highest changes in abundance. It should be noted that there was no overlap in vitreal protein levels between the two groups when the range of levels for each group was considered.

Among the proteins with decreased abundance, we identified PEDF, a protein with anti-angiogenic properties, which has previously been reported to be decreased in the vitreous fluid of PDR patients $[15,16]$. The identification of this protein as decreased in abundance, as would be expected, provides an internal control for this comparative proteomic analysis. The other two proteins displaying decreases in abundance were IRBP and inter- $\alpha$-trypsin inhibitor heavy chain-2 (ITIH2).
The proteins showing increases in abundance included fibrinogen A, ZAG, apolipoprotein (apo) A1, apoH and several members of the complement system (factor B, C3, $\mathrm{C} 9$ and $\mathrm{C} 4-\mathrm{B})$. Complement $\mathrm{C} 3$ was identified at two different groups of spots with molecular masses of about $42 \mathrm{kDa}$ and $75 \mathrm{kDa}$ (average ratio PDR/MH 1.64 and 1.30, respectively), consistent with two of the bands observed by western blot analysis (see below). Regarding C4, a fragment of about $42 \mathrm{kDa}$ was observed, which, according to the mass values of the peptides matching the sequence, can be assigned to fragment C4d-B (amino acids 957-1325).

Western blot analysis To validate the results obtained in the proteomic study we selected five candidate proteins differentially produced in PDR patients to be directly assessed by western blotting. These proteins were ZAG, C3, factor B (which were overproduced in the vitreous fluid of PDR patients), PEDF and IRBP (which were underproduced in the vitreous fluid of PDR patients) (Figs. 2 and 3). These proteins were analysed in the samples used in DIGE and an additional set of four PDR and four MH vitreous samples.

Table 1 Proteins presenting significant differences in abundance in PDR vs MH vitreous fluid

\begin{tabular}{|c|c|c|c|c|c|c|c|c|c|c|c|}
\hline \multirow{2}{*}{$\begin{array}{l}\text { Average } \\
\text { ratio } \\
\mathrm{PDR} / \mathrm{MH}^{\mathrm{a}}\end{array}$} & \multirow{2}{*}{$\begin{array}{l}\text { No. of } \\
\text { spots }^{b}\end{array}$} & \multirow{2}{*}{$\begin{array}{l}\text { Protein } \\
\text { identification }\end{array}$} & \multirow{2}{*}{$\begin{array}{l}\text { Swiss- } \\
\text { Prot } \\
\text { Access }\end{array}$} & \multicolumn{2}{|c|}{ Theoretical } & \multicolumn{2}{|c|}{ Observed } & \multirow{2}{*}{$\begin{array}{l}\text { Mascot } \\
\text { score }^{\mathrm{d}}\end{array}$} & \multirow{2}{*}{$\begin{array}{l}\text { Matched } \\
\text { peptides }^{\mathrm{e}}\end{array}$} & \multirow{2}{*}{$\begin{array}{l}\text { Sequence } \\
\text { coverage } \\
(\%)\end{array}$} & \multirow{2}{*}{$\begin{array}{l}\text { Intensity } \\
\text { coverage }^{\mathrm{f}} \\
(\%)\end{array}$} \\
\hline & & & & $\mathrm{pI}$ & $\begin{array}{l}\text { Molecular } \\
\text { mass } \\
(\mathrm{Da})^{\mathrm{c}}\end{array}$ & $\mathrm{pI}$ & $\begin{array}{l}\text { Molecular } \\
\text { mass } \\
(\mathrm{kDa})\end{array}$ & & & & \\
\hline 6.23 & 1 & $\begin{array}{l}\text { Fibrinogen A, } \\
\text { alpha } \\
\text { polypeptide }\end{array}$ & P02671 & 5.79 & 91358 & 9.5 & 22 & $114(58)$ & $8(6)$ & 13.5 & 68.4 \\
\hline 2.16 & 5 & $\begin{array}{l}\text { Beta2- } \\
\text { glycoprotein-I } \\
(\text { apoH) }\end{array}$ & P02749 & 8.37 & 36254 & 6.3 & 70 & $175(44)$ & $17(16)$ & 69.9 & 63.9 \\
\hline 1.90 & 3 & $\begin{array}{l}\text { Complement } \\
\text { factor B }\end{array}$ & P00751 & 6.66 & 83000 & 6.0 & 100 & $181(60)$ & $27(47)$ & 44.1 & 66.4 \\
\hline 1.72 & 4 & ZAG & P25311 & 5.58 & 32144 & 4.0 & 41 & $207(54)$ & $18(20)$ & 50.9 & 70.8 \\
\hline 1.64 & 3 & Complement $\mathrm{C} 3$ & P01024 & 6.00 & 184967 & 4.0 & 45 & $238(88)$ & $24(17)$ & 12.6 & 73.7 \\
\hline 1.62 & 1 & Complement C9 & P02748 & 5.42 & 60978 & 4.6 & 75 & $110(52)$ & $14(12)$ & 36.4 & 81.1 \\
\hline $1.57^{\mathrm{g}}$ & 1 & $\begin{array}{l}\text { Complement } \\
\text { C4-B (C4d-B } \\
\text { fragment) }\end{array}$ & P0C0L5 & 5.03 & 40620 & 4.0 & 42 & $84(30)$ & $8(21)$ & 36.5 & $28.1^{\mathrm{a}}$ \\
\hline 1.43 & 3 & apoA1 & P02647 & 5.27 & 28078 & 4.5 & 28 & $154(44)$ & $12(8)$ & 48.6 & 76.0 \\
\hline-2.58 & 2 & ITIH2 & P19823 & 5.75 & 72425 & 3.8 & 130 & $89(46)$ & $15(18)$ & 19.4 & 70.9 \\
\hline-2.67 & 5 & PEDF & P36955 & 5.90 & 44418 & 6.5 & 50 & $146(45)$ & $16(16)$ & 41.9 & 80.4 \\
\hline-2.77 & 4 & IRBP & P10745 & 4.98 & 133415 & 4.1 & 137 & $208(47)$ & $35(37)$ & 44.5 & 79.9 \\
\hline
\end{tabular}

${ }^{a}$ This is the abundance ratio averaged from the different gels of the DIGE experiment and for the different spots observed for each protein. Only the spots with a $p$ value of $<0.05$ in the Student's $t$ test for the abundance ratio between the different samples have been averaged

${ }^{b}$ This column refers to the number of spots in each gel corresponding to different forms of the same protein

${ }^{\mathrm{c}}$ The theoretical molecular mass has been calculated from the amino acid sequence reported for the mature protein

${ }^{\mathrm{d}}$ Mascot search scores are shown for the top match and, in parenthesis, for the highest ranked hit to a non-homologous protein

'This column shows the number of peptides that matching the 'top match' protein and, in parenthesis, the number of unmatched peptides in the spectra

${ }^{\mathrm{f}}$ Percentage of the total intensity of the spectrum corresponding to the matched peptides

${ }^{g}$ Complement $\mathrm{C} 4$ was identified as a mixture with complement $\mathrm{C} 3$. The abundance ratio cannot therefore be considered accurate 

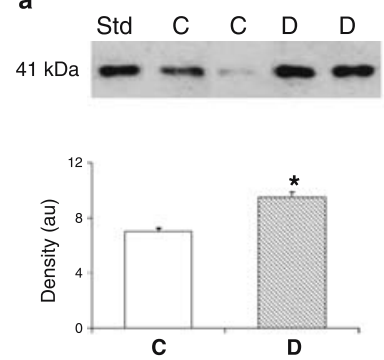

c
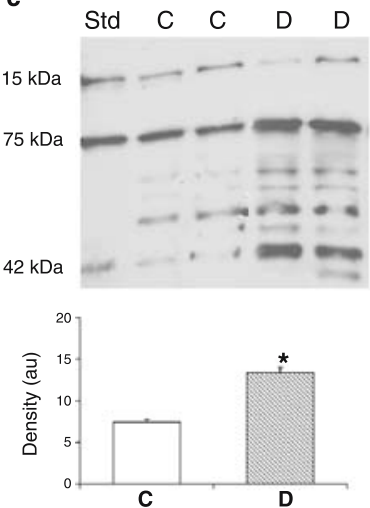

e
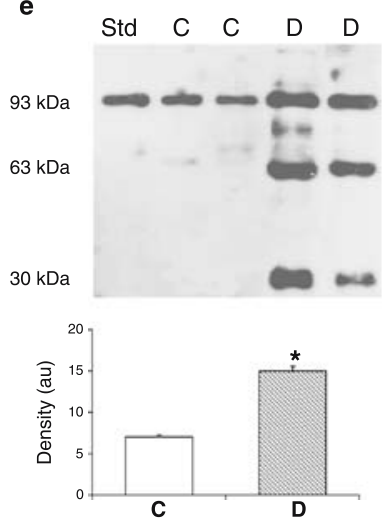

b
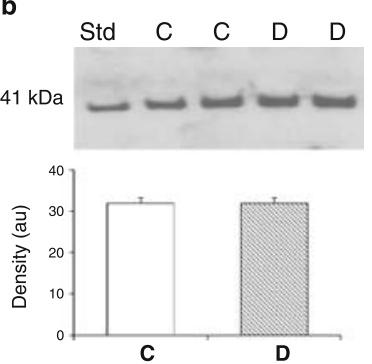

d
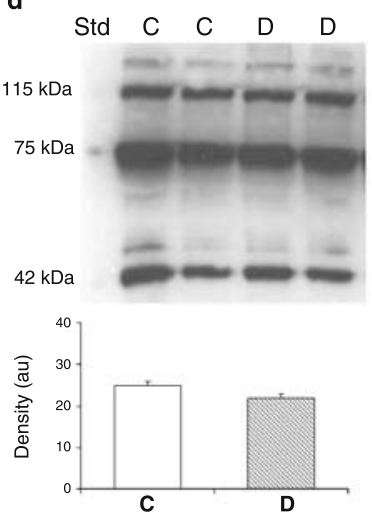

f
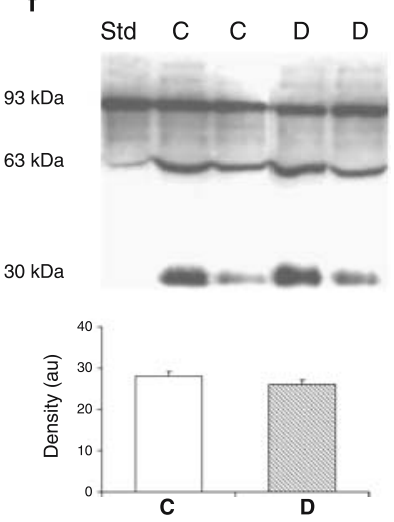

Fig. 2 Western blot analyses of vitreous $(\mathbf{a}, \mathbf{c}, \mathbf{e})$ and serum $(\mathbf{b}, \mathbf{d}, \mathbf{f})$ samples corresponding to three proteins overproduced in the vitreous fluid of PDR patients. Vitreous levels of ZAG $(\mathbf{a}, \mathbf{b}), \mathrm{C} 3$ (fragment of $42 \mathrm{kDa})(\mathbf{c}, \mathbf{d})$ and factor B (e, f) were 1.37-, 1.88- and 2.16-fold higher in PDR patients than the control group $\left({ }^{*} p<0.01\right)$. No differences in serum abundance were observed. Standard purified proteins were used as positive controls for analysing C3 (human C3; Calbiochem, CA, USA) and factor B (human factor B, binding site). Purified human ZAG was provided by Luís Sánchez (University of Oviedo, Spain). $C$ control group, $D$ diabetic group, Std standard

ZAG, C3 (42 kDa fraction) and factor $\mathrm{B}$ (93 kDa fraction) were significantly higher in PDR patient samples than control group samples $(9.57 \pm 0.12$ vs $6.99 \pm 0.73, p=$ $0.003 ; 14.12 \pm 0.21$ vs $7.49 \pm 0.29, p=0.018$; and $15.11 \pm$ 3.12 vs $6.98 \pm 1.34, p=0.005$; Fig. 2). Both $\mathrm{C} 3$ and factor $\mathrm{B}$ presented additional fragments, thus indicating the presence of their activation products. The patterns observed in our vitreous samples were consistent with the native $\alpha$ and $\beta$ chains of C3 (115 and $75 \mathrm{kDa})$ and the presence of other

smaller bands, with the $42 \mathrm{kDa}$ fragment (corresponding to the breakdown of $\mathrm{C} 3 \mathrm{~b}$ [17]) being the most apparent. Factor $\mathrm{B}$ patterns showed a major band of $93 \mathrm{kDa}$ and two fragments consistent with breakdown fragments of $63 \mathrm{kDa}$ $(\mathrm{Bb})$ and $30 \mathrm{kDa}(\mathrm{Ba})$ [18].

By contrast, the intravitreous amounts of PEDF and IRBP were significantly lower in the PDR group than the control group $(6.76 \pm 0.97$ vs $18.25 \pm 8.9, p=0.03$; and $6.48 \pm 0.79$ vs $13.22 \pm 4.98, p=0.04$; Fig. 3).

The average ratios of abundance determined for all the proteins assayed by western blot analysis were in very good agreement with those observed by DIGE proteomic analysis, as shown by plotting the changes observed by the two methodologies against each other (Fig. 4). This is particularly relevant given that one set of samples used for western blot analysis were different from those used for proteomic analysis. Additionally, this consistency supports the assumption that affinity depletion treatment does not significantly alter the quantitative comparison of the samples by DIGE analysis.

There were no differences between PDR patients and control subjects in serum amounts of the proteins analysed (Figs. 2 and 3). Since IRBP is only intra-ocularly produced, it was not detected in any serum samples.

Quantitative real-time RT-PCR Comparative mRNA expression between diabetic and non-diabetic retinas
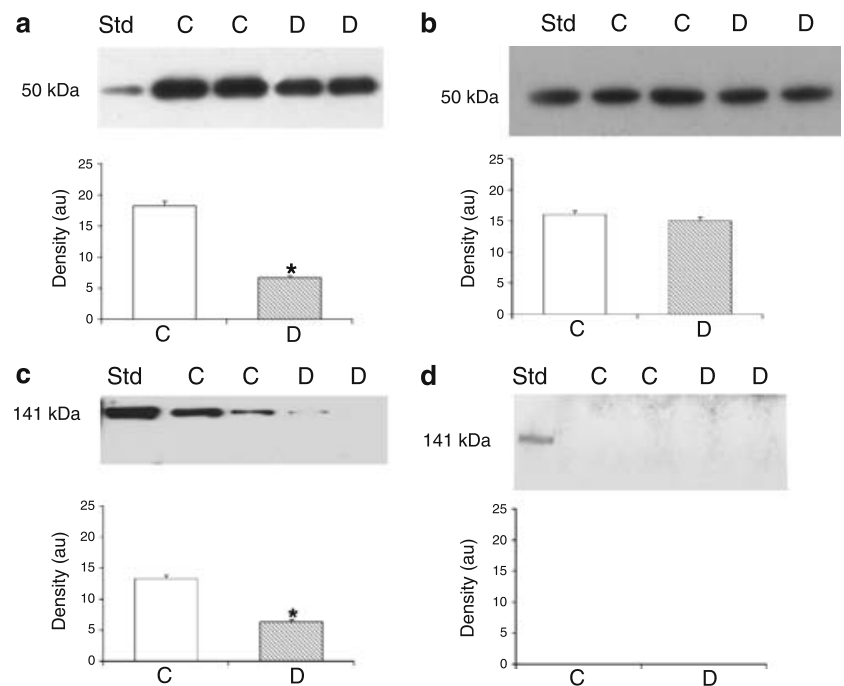

Fig. 3 Western blot analyses of vitreous $(\mathbf{a}, \mathbf{c})$ and serum $(\mathbf{b}, \mathbf{d})$ samples corresponding to two proteins underproduced in the vitreous fluid of PDR patients. Vitreous levels of PEDF $(\mathbf{a}, \mathbf{b})$ and $\operatorname{IRBP}(\mathbf{c}, \mathbf{d})$ were 2.7- and twofold lower in PDR patients than the control group $\left({ }^{*} p<0.05\right)$. No differences in serum abundance were observed. A standard purified protein was used as a positive control for analysing PEDF (Upstate, Charlottesville, VA, USA), and a retina extract was used as a positive control for measuring IRBP. $C$ control group, $D$ diabetic group, Std standard 


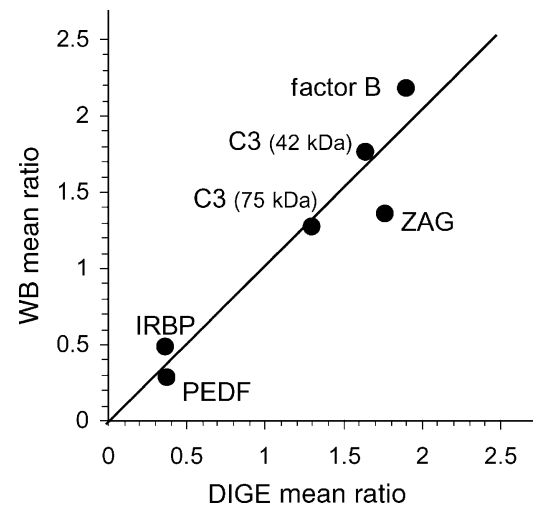

Fig. 4 Comparison of the changes in abundance observed by the DIGE analysis and by western blot (WB) analysis. The average ratio between PDR and control samples observed in WB analysis is plotted against the corresponding average ratio observed by DIGE for each of the indicated proteins

corresponding to $A Z G P 1, C 3, C F B, S E R P I N F 1$ and $R B P 3$ (the genes encoding the proteins $\mathrm{ZAG}, \mathrm{C} 3$, factor $\mathrm{B}, \mathrm{PEDF}$ and IRBP, respectively) is shown in Fig. 5. At the retinal level, the mRNA expression of the proteins that were more abundant in the vitreous fluid of PDR patients was also higher in diabetic donors than non-diabetic donors. However, the difference was only statistically significant for $C F B$. Regarding proteins underproduced in the vitreous fluid of PDR, both SERPINF1 and RBP3 mRNA expression were lower in the retinas from diabetic donors than in the retinas from non-diabetic donors, and the difference was significant for PEDF.

\section{Discussion}

The vitreous provides a means of indirectly exploring the events that are taking place in the retina. However, there is little information on the proteomic analysis of the intravitreal proteins differentially produced in PDR patients in comparison with non-diabetic subjects. In the present study we have optimised the proteomic analysis of vitreous fluid in PDR patients in several ways. First, we facilitated the identification of potential candidates by depleting the two most abundant proteins (albumin and $\mathrm{IgG}$ ) prior to electrophoresis. It has been reported that albumin and $\operatorname{IgG}$ account for more than $80 \%$ of whole-vitreous protein, and the large spots of these proteins overlap other small spots, corresponding to less abundant proteins, so precluding their identification. Second, DIGE, which permits an accurate quantitative comparison, was used for the first time to analyse vitreous samples. Third, the results were validated by western blotting on a different set of samples. Fourth, blood contamination was ruled out by selecting vitreous samples with haemoglobin levels $<5 \mathrm{mg} / \mathrm{ml}$. Fifth, the difference in vitreal protein levels between the PDR patients and control subjects was determined by loading the same amounts of total protein onto a gel. Sixth, vitreous samples from PDR patients were carefully selected so as to minimise biological variation, which could be erroneously interpreted as being diseasespecific. Using this new approach, 11 proteins were identified as differentially produced in the vitreous fluid of PDR patients in comparison with vitreous samples from non-diabetic subjects; eight were overproduced (ZAG, apoA1, apoH,
Fig. 5 Levels of $A Z G P 1$ (a), $C F B$ (b), $C 3$ (c), SERPINF1 (d) and RBP3 (e) mRNAs, as measured by real-time RT-PCR (TaqMan Assay) in retinas from non-diabetic (white bars) and diabetic donors (black bars). Gene expression data $\left(\Delta \Delta \mathrm{C}_{\mathrm{t}}\right)$ are shown after normalising with the gene for $\beta$-actin. Results are presented as the means \pm SEM. ${ }^{*} p<0.05$ vs control group. $C$ control group, $D$ diabetic group
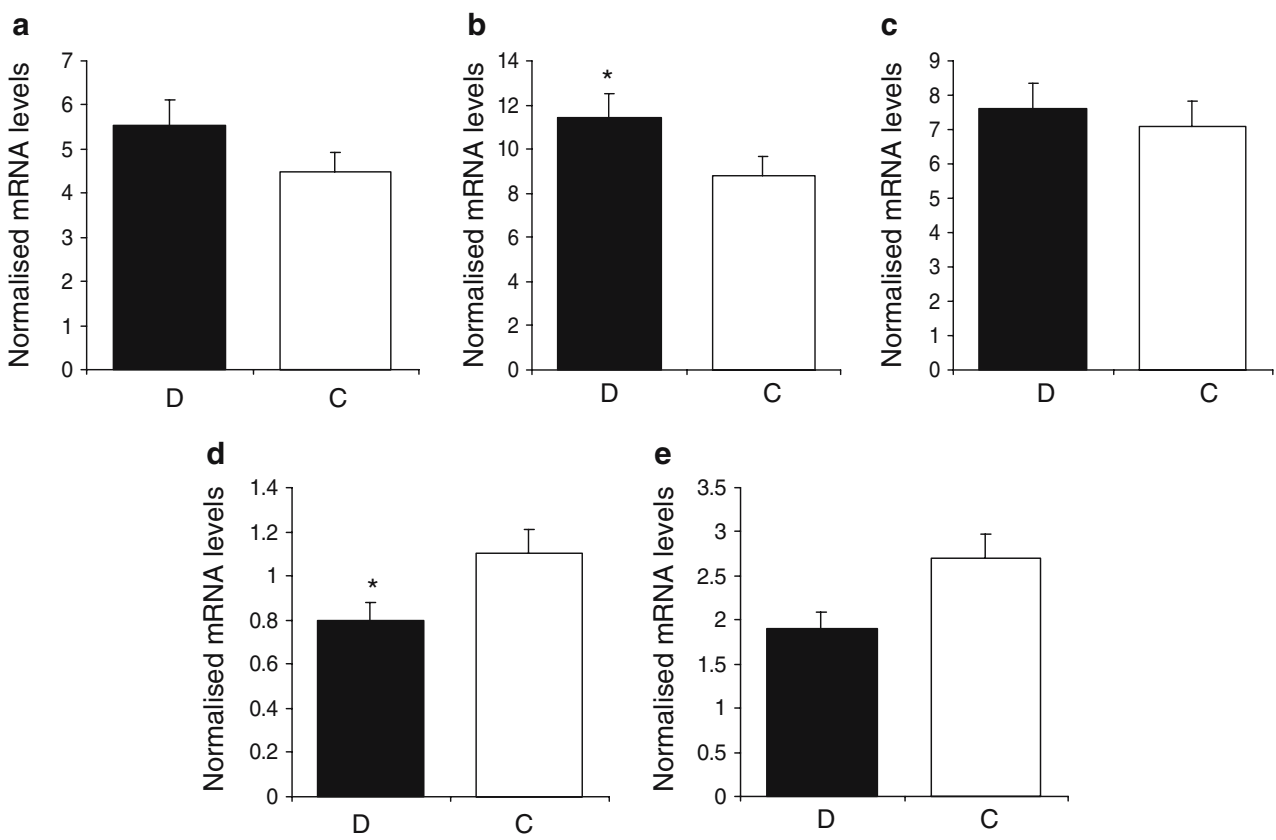
fibrinogen $\mathrm{A}$ and several components of the complement system, namely, C4b, factor B, C3 and C9) and three were significantly underproduced (PEDF, IRBP and ITIH2). The differences observed in five of these 11 proteins (ZAG, C3, factor $\mathrm{B}, \mathrm{PEDF}$ and IRBP) were analysed and confirmed by western blotting.

Although no differences were observed between the two groups in terms of serum levels of the five proteins, determined by western blotting, and in spite of the abovementioned optimisation, it might be claimed that increased leakage of plasma components through the blood-retina barrier could account for increased concentrations of certain proteins in the vitreous. However, we have found that mRNA expression in retinas from diabetic donors without clinically detectable retinopathy is consistent with the results of both DIGE and western blot analyses. Therefore, eye production rather than serum diffusion seems to be the main factor accounting for the different protein abundances detected in diabetic patients. In addition, this result suggests that the differential production of the five candidates identified by DIGE is an early event in the development of diabetic retinopathy. The potential relevance of these proteins in the pathogenesis of PDR is discussed below.

ZAG is a $41-\mathrm{kDa}$ soluble protein, identified by Sanchez et al. [19] as a fat-depleting factor, which is related to MHC class I molecules. Although its biological functions are incompletely understood, it seems to be a novel adipokine that may be involved in the local regulation of adipose tissue function [20-23]. ZAG has been recently identified by proteomic analysis in vitreous fluid from PDR patients $[8,9]$. In the present study we have confirmed this finding. In addition, both DIGE proteomic analysis and western blotting indicated that ZAG production was significantly higher in the vitreous fluid from PDR patients compared with that from non-diabetic patients. We do not why ZAG levels are increased in the vitreous of diabetic patients with PDR, but it should be noted that hyperglycaemia has been involved in ZAG production [23], and gene expression of ZAG has been found to be upregulated in mice with diabetic nephropathy [24]. In addition, ZAG hinders cell proliferation and reduces $C d c 2$ expression (a rate-limiting step in cell cycle) [25] and may therefore be a reactive limiting factor for PDR progression. Obviously, the mechanisms involved in the intraocular production of ZAG and its role in the pathogenesis of diabetic retinopathy require further investigation.

In recent years evidence has accumulated indicating that inflammation is an important event in the pathogenesis of diabetic retinopathy [26-28]. In the present study, vitreous levels of several components of the complement system (C4b, factor B, C3 and C9) have been found, for the first time, to be simultaneously increased in PDR patients relative to control subjects. In addition, $\mathrm{C} 3$ and factor $\mathrm{B}$, as well as their activation products, have been confirmed as increased by western blot analysis. Although complement activation could be secondary to the inflammatory process, in recent studies on human and experimental non-proliferative diabetic retinopathy, Zhang et al. [29] have demonstrated an early complement activation associated with a prominent and selective decrease in the levels of CD55 and CD59, two glycosylphosphatidylinositol-anchored complement inhibitors. In addition, these authors have shown that $\mathrm{C} 1 \mathrm{q}$ and $\mathrm{C} 4$, the complement components unique to the classical pathway, were not detected in diabetic retinas, thus suggesting that the alternative pathway is the main mechanism of complement activation in the early stages of diabetic retinopathy. In our study, apart from factor B, which is a specific component of the alternative activation pathway, higher intravitreal levels of $\mathrm{C} 4$ were detected in PDR subjects. Therefore, classical pathway activation also seems to be involved in the advanced stages of diabetic retinopathy. In fact, intravitreal $\mathrm{C} 4$ has been found to be increased in patients with non-diabetic proliferative vitreoretinopathy [30]. Activation of the complement cascade can both compound and initiate thrombosis, leucostasis and apoptosis, all of which are processes involved in vascular lesions of diabetic retinopathy. Interestingly, it has been reported that the inhibition of aldose reductase prevents the activation of complement in the wall of retinal vessels and decreased levels of complement inhibitors in diabetic rats [31]. Therefore, since several ways of specifically manipulating the complement system already exist, they could represent a possible therapeutic approach in diabetic retinopathy.

PEDF is mainly secreted by retinal pigment epithelial cells in the eye, as well as by other body tissues [32]. Apart from its neurotrophic and neuroprotective properties, there is growing evidence to suggest that PEDF is among the most important natural inhibitors of angiogenesis, and that it is the main factor accounting for the anti-angiogenic activity of the vitreous fluid, where it is found in abundant quantities [32, 33]. The relevance of PEDF to human neovascular disease is supported by studies showing that decreased levels of PEDF in the vitreous are associated with PDR $[15,16]$. We have confirmed a PEDF deficit in the vitreous fluid of diabetic patients with PDR by both proteomic analysis and western blotting. In addition, it should be noted that the upregulation of PEDF in proliferating retinal pigment epithelial cells may, in part, account for the success of pan-retinal photocoagulation in reducing neovascularisation [34]. Therefore, there are good reasons for proposing PEDF as a serious candidate for diabetic retinopathy treatment.

IRBP is a large glycoprotein (molecular mass $\sim 140 \mathrm{kDa}$ ) that constitutes approximately $70 \%$ of the protein component of the interphotoreceptor matrix, in which it has a highly restricted tissue-specific expression [35]. IRBP plays a major role in the visual cycle $[36,37]$ and, therefore, the 
lower levels detected in PDR patients could be involved in the impairment of vision detected in these patients. Further studies investigating the precise role of IRBP in diabetic retinopathy are needed.

There are two main limitations to the present study. The first involves the intrinsic limitations of 2-DE in the analysis of complex protein mixtures. Proteins of very high or low molecular mass are frequently precluded from the analysis by the electrophoresis procedure itself. Conversely, even after depletion of the very abundant proteins, both detection in 2DE and identification by MS are limited by the abundance of the proteins of the mixture, in that minor components will always escape analysis. Therefore, potential candidates involved in the pathogenesis of diabetic retinopathy at picogram levels, such as vascular endothelial growth factor (VEGF), cannot be identified. The second limitation pertains to the rigorous selection of vitreous samples, which precludes the inclusion of an ample set of samples and may consequently impede the consideration of other potential candidate proteins that exist in the vitreous fluid of PDR patients. However, although the number of samples included in this study was relatively low, the selection process enabled us to minimise the dispersion of the measurements in each group. The observed differences by DIGE were further validated by western blot analysis of samples from different patients, which confirmed the observed differences with good quantitative agreement. Therefore, although additional differentially expressed proteins could probably be identified by the analysis of a larger set of samples, those reported here would probably also be found.

In summary, we have shown that two-dimensional DIGE, by providing an accurate quantitative comparison, could facilitate the identification of new potential candidate proteins involved in the development of PDR. Further studies are needed to address the precise role of these candidates in the pathogenesis of PDR and their potential as therapeutic targets.

Acknowledgements This study was supported by grants from Novo Nordisk Pharma SA (01/0066), the Ministerio de Sanidad y Consumo. Instituto de Salud Carlos III (RED DIABETES- REDIMET), and the Ministerio de Ciencia y Tecnología (SAF2003-00550 and SAF200605284). The proteomics laboratory at the IR-HUVH belongs to the Spanish National Institute of Proteomics (PROTEORED). We are grateful to L. M. Sánchez (University of Oviedo, Spain), for providing us with rabbit antihuman ZAG, and to J. M. Nickerson (Emory University, Atlanta, GA, USA), for providing us with the antibodies against IRBP.

Duality of interest We declare that we have no duality of interest.

\section{References}

1. Congdon N, Friedman DS, Lietman T (2003) Important causes of visual impairment in the world today. JAMA 290:2057-2060
2. Burgos R, Mateo C, Canton R, Hernandez C, Mesa J, Simo R (2000) Vitreous levels of IGF-1, IGF binding protein 1, and IGF binding protein 3 in proliferative diabetic retinopathy. A casecontrol study. Diabetes Care 23:80-83

3. Simo R, Lecube A, Segura RM, Garcia-Arumi J, Hernandez C (2002) Free insulin growth factor-I and vascular endothelial growth factor in the vitreous fluid of patients with proliferative diabetic retinopathy. Am J Ophthalmol 134:376-382

4. Simo R, Lecube A, Sararols L, Garcia-Arumi J, Segura RM, Hernandez C (2002) Deficit of somatostatin-like immunoreactivity in the vitreous fluid of diabetic patients. Diabetes Care 25:2282-2286

5. Simo R, Carrasco E, Garcia-Ramirez M, Hernandez C (2006) Angiogenic and antiangiogenic factors in proliferative diabetic retinopathy. Curr Diab Rev 2:71-98

6. Gorg A, Weiss W, Dunn MJ (2004) Current two-dimensional electrophoresis technology for proteomics. Proteomics 4:36663685

7. Nakanishi T, Koyama R, Ikeda T, Shimizu A (2002) Catalogue of soluble proteins in the human vitreous humor: comparison between diabetic retinopathy and macular hole. J Chromatogr B Analyt Technol Biomed Life Sci 776:89-100

8. Koyama R, Nakanishi T, Ikeda T, Shizimu A (2003) Catalogue of soluble proteins in human vitreous humor by one-dimensional sodium dodecyl sulfate-polyacrylamide gel electrophoresis and electrospray ionization mass spectrometry including seven angiogenesis-regulating factors. J Chromatogr B Analyt Technol Biomed Life Sci 792:5-21

9. Yamane K, Minamoto A, Yamashita H et al (2003) Proteome analysis of human vitreous proteins. Mol Cell Proteomics 2:1177-1187

10. Wu CH, Sauter JL, Johnson PK, Chen CD, Olsen TW (2004) Identification and localization of major soluble vitreous proteins in human ocular tissue. Am J Ophthalmol 137:655-661

11. Ouchi M, West K, Crabb JW, Kinoshita S, Kamei M (2005) Proteomic analysis of vitreous from diabetic macular edema. Exp Eye Res 81:176-182

12. Wilson AS, Hobbs BG, Shen WY et al (2003) Argon laser photocoagulation-induced modification of gene expression in the retina. Invest Ophthalmol Vis Sci 44:1426-1434

13. Alban A, David SO, Bjorkesten L et al (2003) A novel experimental design for comparative two-dimensional gel analysis: two-dimensional difference gel electrophoresis incorporating a pooled internal standard. Proteomics 3:36-44

14. Shevchenko A, Wilm M, Vorm O, Mann M (1996) Mass spectrometric sequencing of proteins from silver-stained polyacrylamide gels. Anal Chem 68:850-858

15. Spranger J, Osterhoff M, Reimann M et al (2001) Loss of the antiangiogenic pigment epithelium-derived factor in patients with angiogenic eye disease. Diabetes 50:2641-2645

16. Ogata N, Tombran-Tink J, Nishikawa M et al (2001) Pigment epithelium-derived factor in the vitreous is low in diabetic retinopathy and high in rhegmatogenous retinal detachment. Am J Ophthalmol 132:378-382

17. Cunnion KM, Hair PS, Buescher ES (2004) Cleavage of complement $\mathrm{C} 3 \mathrm{~b}$ to $\mathrm{iC} 3 \mathrm{~b}$ on the surface of Staphylococus aureus is mediated by serum complement factor I. Infect Immun 72:2858-2863

18. Thomas A, Gasque P, Vaudry D, Gonzalez B, Fontaine M (2000) Expression of a complete and functional complement system by human neuronal cells in vitro. Int Immunol 12:1015-1023

19. Sanchez LM, Lopez-Otin C, Bjorkman PJ (1997) Biochemical characterization and crystalization of human $\mathrm{Zn}$-alpha2-glycoprotein, a soluble class I major histocompatibility complex homolog. Proc Natl Acad Sci USA 94:4626-4630

20. Bao Y, Bing C, Hunter L, Jenkins JR, Wabitsh M, Trayhurn P (2005) Zinc-alpha2-glycoprotein, a lipid mobilizing factor, is expressed and secreted by human (SGBS) adipocytes. FEBS Lett 579:41-47 
21. Bing C, Bao Y, Jenkins J et al (2004) Zinc-alpha2-glycoprotein, a lipid mobilizing factor, is expressed in adipocytes and is upregulated in mice with cancer cachexia. Proc Natl Acad Sci USA 101:2500-2505

22. Russell ST, Zimmerman TP, Domin BA, Tisdale MJ (2003) Induction of lipolysis in vitro and loss of body fat in vivo by zincalpha2-glycoprotein. Biochim Biophys Acta 1636:59-68

23. Gohda T, Makita Y, Shike T et al (2003) Identification of epistatic interaction involved in obesity using the $\mathrm{KK} / \mathrm{Ta}$ mouse as a type 2 diabetes model: is $\mathrm{Zn}$-alpha2 glycoprotein-1 a candidate gene for obesity? Diabetes 52:2175-2181

24. Gohda T, Tanimoto M, Shiina K et al (2004) Altered mouse cholinephosphotransferase gene expression in kidneys of type 2 diabetic KK/TA mouse. Metabolism 53:842-846

25. He N, Brysk H, Tyring SK, Ohkubo I, Brysk MM (2001) Zincalpha $_{2}$-glycoprotein hinders cell proliferation and reduces $C d c 2$ expression. J Cell Biochem 81:162-169

26. Joussen AM, Poulaki V, Le ML et al (2004) A central role of inflammation in the pathogenesis of diabetic retinopathy. FASEB J 18:1450-1452

27. Meleth AD, Agron E, Chan CC et al (2005) Serum inflammatory markers in diabetic retinopathy. Invest Opthalmol Vis Sci 46: 4295-4301

28. Hernandez C, Segura RM, Fonollosa A, Carrasco E, Francisco G, Simo R (2005) Interleukin-8, monocyte chemoattractant protein-1 and IL-10 in the vitreous fluid of patients with proliferative diabetic retinopathy. Diabet Med 22:710-722

29. Zhang J, Gerhardinger C, Lorenzi M (2002) Early complement activation and decreased levels of glycosylphosphatidylinositol- anchored complement inhibitors in human and experimental diabetic retinopathy. Diabetes 51:3499-3504

30. Grisanti S, Wiedemann P, Weller M, Heimann K, Zilles K (1991) The significance of complement in proliferative vitreoretinopathy. Invest Ophthalmol Vis Sci 32:2711-2717

31. Dagher Z, Park YS, Asnaghi V, Hoehn T, Gerhardinger C, Lorenzi M (2004) Studies of rat and human retinas predict a role for the polyol pathway in human diabetic retinopathy. Diabetes 53:2404-2411

32. Barnstable CJ, Tombran-Tink J (2004) Neuroprotective and antiangiogenic actions of PEDF in the eye: molecular targets and therapeutic potential. Prog Retin Eye Res 23:561-577

33. Dawson DW, Volpert OV, Gilis P et al (1999) Pigment epitheliumderived factor: a potent inhibitor of angiogenesis. Science 285: 245-248

34. Ogata N, Tombran-Tink J, Jo N, Mrazek D, Matsumura M (2001) Upregulation of pigment epithelium-derived factor after laser photocoagulation. Am J Ophthalmol 132:427-429

35. Chader GJ (1989) Interphotoreceptor retinoid-binding protein (IRBP): a model protein for molecular biological and clinically relevant studies. Friedenwald lecture. Invest Ophthalmol Vis Sci 30:7-22

36. Liou GI, Bridges CD, Fong SL, Alvarez RA, Gónzalez-Fernandez F (1982) Vitamin A transport between retina and pigment epithelium - an interstitial protein carrying endogenous retinol (interstitial retinol-binding protein). Vision Res 22:1457-1467

37. Pepperberg DR, Okajima TL, Wiggert B, Ripps H, Crouch RK, Chader GJ (1993) Interphotoreceptor retinoid-binding protein (IRBP). Molecular biology and physiological role in the visual cycle of rhodopsin. Mol Neurobiol 7:61-85 